\title{
CHEMICAL CONSTITUENTS AND TOXICITY OF ESSENTIAL OILS OF ORIENTAL ARBORVITAE, Platycladus orientalis (L.) FRANCO, AGAINST THREE STORED-PRODUCT BEETLES
}

\author{
Seyed Mehdi Hashemi ${ }^{*}$, and Seyed Ali Safavi ${ }^{1}$
}

\begin{abstract}
Plant secondary metabolites play an important role in plant-insect interactions and therefore such compounds may have insecticidal or biological activity against insects. Fumigant toxicity of essential oils of leaves and fruits from oriental arborvitae (Platycladus orientalis [L.] Franco) (Cupressaceae) was investigated against adults of cowpea weevil (Callosobruchus maculatus Fab.), rice weevil (Sitophilus oryzae L.), and red flour beetle (Tribolium castaneum Herbst). Fresh leaves and fruits were subjected to hydrodistillation using a Clevenger-type apparatus and the chemical composition of the volatile oils was studied by gas chromatography-mass spectrometry (GC-MS). Twenty-six compounds (92.9\%) and 23 constituents $(97.8 \%)$ were identified in the leaf and the fruit oils, respectively. The major components of both leaves and fruits oils were $\alpha$-pinene $(35.2 \%, 50.7 \%), \alpha$-cedrol $(14.6 \%, 6.9 \%)$ and $\Delta$-3-carene $(6.3 \%, 13.8 \%)$, respectively. Both oils in the same concentration were tested for their fumigant toxicity on each species. Results showed that leaf oils were more toxic than fruit oils against three species of insects. Callosobruchus maculatus was more susceptible than $S$. oryzae and $T$. castaneum. $\mathrm{LC}_{50}$ values of the leaf and the fruit oils at $24 \mathrm{~h}$ were estimated 6.06 and $9.24 \mu \mathrm{L} \mathrm{L}^{-1}$ air for C. maculatus, 18.22 and $21.56 \mu \mathrm{L} \mathrm{L}^{-1}$ air for $S$. oryzae, and 32.07 and $36.58 \mu \mathrm{L} \mathrm{L}^{-1}$ air for $T$. castaneum, respectively. These results suggested that $P$. orientalis oils may have potential as a control agent against $C$. maculatus, $S$. oryzae, and $T$. castaneum.
\end{abstract}

Key words: Botanical insecticides, fumigation, Platycladus orientalis, stored-product insects.

$\mathrm{I}_{\mathrm{a}}^{\mathrm{n}}$ nsect pest often cause extensive damage to stored grains and their products and this may amount to $5-10 \%$ in the temperate zone and 20-30\% in the tropical zone (Haque et al., 2000). In such a situation, protection of stored grain and agricultural products against insect infestation is an urgent need. Synthetic insecticides and fumigation are the main methods in stored product insect pest control. Furthermore, an uncontrolled use of these synthetic insecticides causes a great hazard for environment and consumers due to residues (Isman, 2006). Naturally occurring substances are an alternative to conventional pesticides and plant essential oils have traditionally been used to kill insects (Isman, 2000). Essential oils obtained from plants are under particular investigation for their broad-spectrum pest control properties. They have been shown to possess fumigant activity for stored-product pests (Negahban et al., 2007; Negahban and Moharramipour, 2007; Sahaf et al., 2007; 2008) as contact insecticides (Park et al., 2003). Moreover, their repellent, antifeedants, growth inhibiting, and reproduction-retarding effects have been demonstrated against several storage pests

${ }^{1}$ Urmia University, Faculty of Agriculture, Department of Plant Protection, Urmia, West Azerbaijan, P.O. Box 57135-165, Iran. *Corresponding author (mehdi.ha27@gmail.com).

Received: 26 October 2011.

Accepted: 27 March 2012.
(Huang et al., 1998; Papachristos and Stamopoulos, 2002; Tapondjou et al., 2005; Benzi et al., 2009). Essential oils derived from plant species of Platycladus have been evaluated for insecticidal properties (Keita et al., 2001; Pavela, 2005). However, no report on insecticidal activity of essential oils of $P$. orientalis against cowpea weevil, Callosobruchus maculatus (Fab.), rice weevil, Sitophilus oryzae (L.), and red flour beetle, Tribolium castaneum (Herbst) was available.

All aromatic Iranian conifers belong to Cupressaceae family. In Iran this family consists of one species of Platycladus, one species of Cupressus, and five species of Juniperus. Oriental arborvitae, Platycladus orientalis (L.) Franco [Thuja orientalis L.], locally named Sarv-e Khomreii or Nosh, is an evergreen species, which grows naturally in Iran. Also, this species is widely cultivated as a common ornamental plant in Iran and other countries (Assadi, 1998).

Platycladus orientalis is a medicinal plant whose fresh leaves have been used as an anti-inflammatory (Panthong et al., 1986), while the dried leaves have been used to treat flu and cough (Comerford, 1996), high blood pressure (Panthong et al., 1986), bleeding arthralgia (Mikage et al., 1984), cancer (Sharma et al., 1993), haemostatic (Kosuge et al., 1981), and has also been used in Chinese medicine for the treatment of gout, rheumatism, diarrhea, and chronic tracheitis (Zhu et al., 2004). 
The aim of this study was to analyze chemical constituents of essential oils of leaves and fruits of $P$. orientalis and to identify the active chemical constituents of the essential oils as well as to evaluate its fumigant toxicity in the management of C. maculatus, $S$. oryzae, and $T$. castaneum.

\section{MATERIALS AND METHODS}

\section{Insect culture}

Callosobruchus maculatus, S. oryzae, and T. castaneum were reared on bean grains, whole rice, and wheat flour mixed with yeast $(10: 1, \mathrm{w} / \mathrm{w})$, respectively. Adult insects, 1-7-d old, were used for fumigant toxicity tests. The cultures were maintained in dark in a growth chamber set at $27 \pm 2{ }^{\circ} \mathrm{C}$ and $60 \pm 5 \% \mathrm{RH}$. Parent adults were obtained from laboratory stock cultures maintained at the Entomology Department, University of Urmia, Iran. All experiments were carried out under the same environmental conditions.

\section{Plant material}

The vegetal organs (leaves and fruits) of the P. orientalis were collected during the summer 2010 from the shrubs cultivated in the Department of Horticultural, Urmia University, Nazlo area, $12 \mathrm{~km}$ in the west of Urmia (37 $32^{\circ}$ $\mathrm{N}, 45^{\circ} 05^{\prime} \mathrm{E} ; 1313 \mathrm{~m}$ a.s.1.), Iran. Plant taxonomists in the Department of Biology at Urmia University, confirmed the taxonomic identification of plant species. The voucher specimens have been deposited at the herbarium of the Department of Plant Protection at Urmia University.

\section{Extraction and analysis of essential oils}

Fresh leaves and fruits of the plant were separately hydrodistilled in a Clevenger type apparatus where the plant materials were subjected to hydrodistillation. Conditions of extraction were: $100 \mathrm{~g}$ of fresh sample; 1:10 plant material/water volume ratio, $4 \mathrm{~h}$ distillation. Anhydrous sodium sulphate was used to remove water after extraction. Extracted oils transferred to glass flasks that were filled to the top and kept at the temperature of 4 ${ }^{\circ} \mathrm{C}$ in a refrigerator.

The constituents of $P$. orientalis essential oils were analyzed by gas chromatography-mass spectrometry gas chromatography-mass spectrometry (GC-MS) using a Hewlett-Packard 6890/5972 system with a HP$5 \mathrm{MS}$ capillary column $(30 \mathrm{~m} \times 0.25 \mathrm{~mm} ; 0.25 \mu \mathrm{m}$ film thickness). The carrier gas was helium with flow $1 \mathrm{~mL}$ $\mathrm{min}^{-1}$. The oven temperature was held at $60{ }^{\circ} \mathrm{C}$ for $3 \mathrm{~min}$, programmed at $6{ }^{\circ} \mathrm{C} \mathrm{min}-1$ to $220{ }^{\circ} \mathrm{C}$ and then held at this temperature for $3 \mathrm{~min}$. Mass spectra were taken at 70 ev. Mass range was from $m / z, 35 D 350 \mathrm{amu}$. The injector temperature was $240{ }^{\circ} \mathrm{C}$. Relative percentage amounts were calculated from peaks total area by apparatus software. The compounds were identified by comparing mass spectra and retention indices with those in literatures
(Adams, 1995) and by computer searching followed by matching the mass spectra data with those held in a computer library (Wiley 275.L).

\section{Fumigant toxicity}

To determine the fumigant toxicity of the P.orientalis oils, some concentrations of the leaf and the fruit oils including $2,5,7,10$, and $13 \mu \mathrm{L} \mathrm{L}^{-1}$ air were tested on C. maculatus. Suceptibility of $S$. oryzae was evaluated at 8, 14, 19, 23, and $28 \mu \mathrm{L} \mathrm{L}^{-1}$ air of essential oils. Concentrations were $15,21,28,36$, and $47 \mu \mathrm{L} \mathrm{L}^{-1}$ air for $T$. castaneum. They were dissolved in $100 \mu \mathrm{L}$ acetone and applied to filter papers (Whatman $\mathrm{N}^{\circ} 1$, cut into $4 \times 5 \mathrm{~cm}$ paper strip) was dried in air for $2 \mathrm{~min}$. The impregnated filter papers were put into $1 \mathrm{~L}$ glass bottles. Twenty adults of $C$. maculatus, $S$. oryzae, and T. castaneum (1-7-d old) were placed in small plastic tubes $(3.5 \mathrm{~cm}$ diameter and $5 \mathrm{~cm}$ height) with open ends covered with cloth mesh. The tubes were hung at the geometrical centre of glass bottles, which were then sealed with air-tight lids. In the control bottles, only acetone was applied on the filter papers. Mortality was determined after 24,48 , and $72 \mathrm{~h}$ from commencement of the exposure.

When no leg or antennal movements were observed, insect was considered dead. Insect mortality percentages were calculated using the Abbott correction formula for natural mortality in untreated control (Abbott, 1925).

\section{Data analysis}

Tests arranged as completely randomized design and data were analyzed by one-way ANOVAusing the SAS software version 9.1. Lethal concentrations $\left(\mathrm{LC}_{50}\right.$ and $\left.\mathrm{LC}_{95}\right)$ and lethal time values $\left(\mathrm{LT}_{50}\right.$ and $\mathrm{LT}_{95}$ ) were calculated with SPSS software (version 16.0). Comparison of means were done through Tukey's test $(\alpha=0.01)$.

\section{RESULTS AND DISCUSSION}

\section{Chemical constituents of essential oils}

The main components of both leaves and fruits essential oils from $P$. orientalis were $\alpha$-pinene $(35.2 \%, 50.7 \%)$, $\alpha$-cedrol $(14.6 \%, 6.9 \%), \Delta$-3-carene $(6.3 \%, 13.8 \%)$, limonene $(6.1 \%, 1.5 \%), \beta$-caryophyllene $(5.8 \%, 4.1 \%)$, and myrcene $(3.3 \%, 3.8 \%)$, respectively (Table 1$)$.

\section{Fumigant toxicity}

The concentration of $13 \mu \mathrm{L} \mathrm{L}^{-1}$ air of the leaf oil recorded $100 \%$ mortality of $C$. maculatus after $48 \mathrm{~h}$, but in the same concentration from the fruit oil $100 \%$ mortality of C. maculatus was achieved in $72 \mathrm{~h}$ exposure time. The concentration of $28 \mu \mathrm{L} \mathrm{L}^{-1}$ air from the leaf oil killed $100 \%$ of $S$. oryzae after $72 \mathrm{~h}$ exposure. By contrast with the fruit oil about $93 \%$ mortality was achieved for $S$. oryzae at the same time exposure. At $47 \mu \mathrm{L} \mathrm{L}^{-1}$ air the leaves oil caused $71 \%$ mortality on $T$. castaneum after $24 \mathrm{~h}$ exposure and about $91 \%$ mortality after $72 \mathrm{~h}$. At this concentration from 
Table 1. Chemical composition $(\%)$ of essential oils of oriental arborvitae, Platycladus orientalis.

\begin{tabular}{|c|c|c|c|}
\hline Compound & $\begin{array}{c}\text { Retention } \\
\text { index }\end{array}$ & Leaf oil & Fruit oil \\
\hline & & \multicolumn{2}{|c|}{$\%$} \\
\hline$\alpha$-Thujene & 928 & 0.6 & - \\
\hline$\alpha$-Pinene & 936 & 35.2 & 50.7 \\
\hline$\alpha$-Fenchene & 944 & 1.2 & 1.6 \\
\hline Sabinene & 971 & 1.5 & 2.1 \\
\hline$\beta$-Pinene & 977 & 0.1 & 0.9 \\
\hline Myrcene & 993 & 3.3 & 3.8 \\
\hline$\alpha$-Phellandrene & 1005 & 1.6 & 2.1 \\
\hline$\Delta 3$-Carene & 1013 & 6.3 & 13.8 \\
\hline$\rho$-Cymene & 1021 & 1.4 & 2.0 \\
\hline Limonene & 1032 & 6.1 & 1.5 \\
\hline$\gamma$-terpinene & 1058 & 0.4 & 0.5 \\
\hline Terpinolene & 1063 & 2.1 & 1.7 \\
\hline cis-Sabinene hydrate & 1092 & - & 0.2 \\
\hline Linalool & 1101 & 1.2 & - \\
\hline Terpinen-4-ol & 1177 & 0.1 & 0.3 \\
\hline$\alpha$-Terpineol & 1241 & - & 0.1 \\
\hline Bornyl acetate & 1285 & 0.7 & 1.3 \\
\hline$\alpha$-Terpenyl acetate & 1376 & 0.5 & - \\
\hline$\beta$-Elemene & 1390 & 0.7 & 0.3 \\
\hline$\beta$-Cedrene & 1417 & 1.8 & 0.9 \\
\hline$\beta$-Caryophyllene & 1423 & 5.8 & 4.1 \\
\hline Thujopsene & 1435 & 2.1 & 1.7 \\
\hline$\alpha$-Humolene & 1456 & 1.0 & 0.4 \\
\hline Germacrene-D & 1483 & 2.2 & - \\
\hline$\Delta$-Cadinene & 1515 & 0.3 & 0.3 \\
\hline Elemol & 1541 & 1.5 & 0.6 \\
\hline$\alpha$-Cedrol & 1614 & 14.6 & 6.9 \\
\hline$\alpha$-Cadinol & 1651 & 0.6 & - \\
\hline Total & & 92.9 & 97.8 \\
\hline
\end{tabular}

the fruit oil about $66 \%$ mortality was achieved after $24 \mathrm{~h}$ and $84 \%$ mortality after $72 \mathrm{~h}$ for $T$. castaneum (Figures 1 and 2).

Probit analysis showed that at exposure time of $24 \mathrm{~h}$, C. maculatus was more susceptible than $S$. oryzae, and T. castaneum to both leaf and the fruit oils (Tables 2 and 3). Furthermore, with the increase of exposure time to 72 $\mathrm{h}$, mortality increased and $\mathrm{LC}_{50}$ values decreased to 2.21 and $2.60 \mu \mathrm{L} \mathrm{L}^{-1}$ air for C. maculatus, 9.07 and $10.90 \mu \mathrm{L}$ $\mathrm{L}^{-1}$ air for S. oryzae, and 22.54 and $25.63 \mu \mathrm{L} \mathrm{L}^{-1}$ air for T. castaneum from the leaf and fruits oils, respectively. Morever, slopes of probit lines estimated that any increase in essential oil concentration, was imposed the least mortality to C. maculatus (2.64 and 2.33 , respectively, for leaf and fruit essential oils at $72 \mathrm{~h}$ ) when compared to other tested insects. Furthemore, intercept of probit line for this pest was higher than $S$. oryzae and T. castaneum, showing the higher response threshold (Tables 2 and 3, and Figures 1 and 2). Considering the $\mathrm{R}^{2}$ values, a linear model was fitted for lethal time analysis. $\mathrm{LT}_{50}$ values were 12.87 and $18.89 \mathrm{~h}$ for C. maculatus, 15.25 and $14.55 \mathrm{~h}$ for $S$. oryzae, and 11.31 and $10.72 \mathrm{~h}$ for T. castaneum for the leaf and fruits oils, respectively. $\mathrm{LT}_{50}$ values and their corresponding information were calculated at the highest concentrations $\left(13 \mu \mathrm{L} \mathrm{L}^{-1}\right.$ air for C. maculatus, $28 \mu \mathrm{L}$ $\mathrm{L}^{-1}$ air for S. oryzae, and $47 \mu \mathrm{L} \mathrm{L}^{-1}$ air for T. castaneum). Comparison of slopes of regression lines among three insects showed that $T$. confusum mortality was slowly influenced by time, and conversely, C. maculatus mortality was highly affected by time spent when compared with
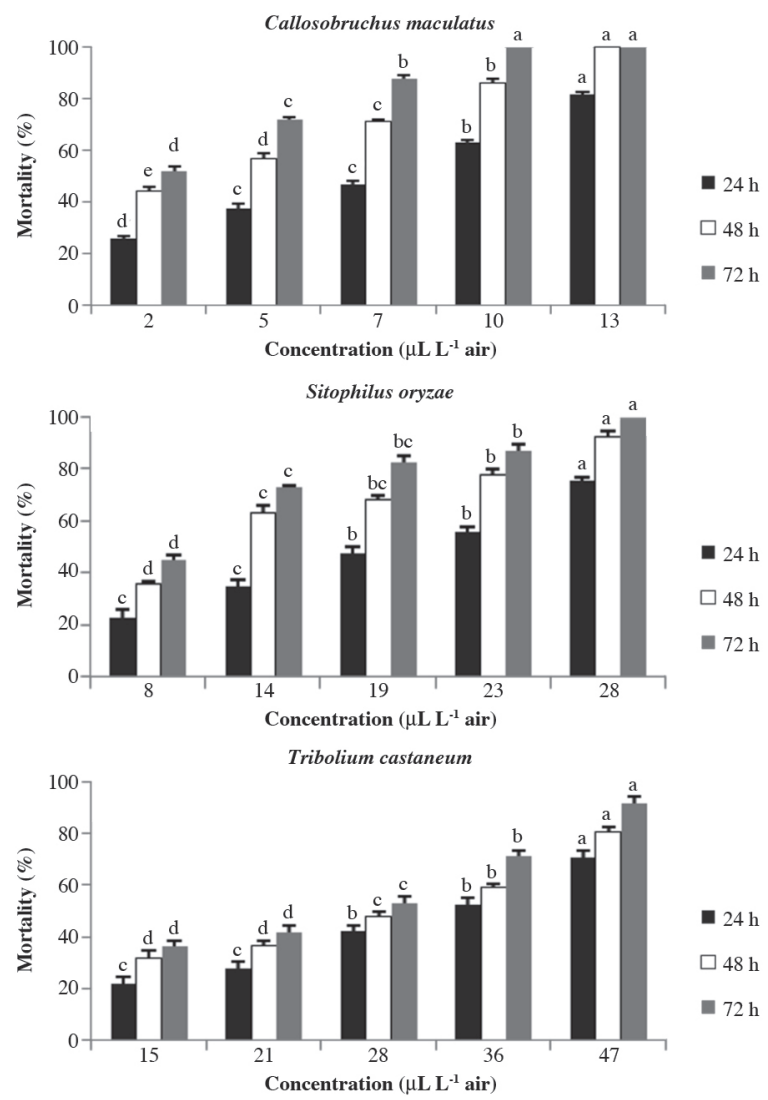

Different letters over columns indicate significant differences according to Tukey test at $\alpha$ $=0.01$. Columns with the same letter are not significantly different. Vertical bars indicate standard error $( \pm)$

Figure 1. Mean mortality (\%) of Callosobruchus maculatus, Sitophilus oryzae, and Tribolium castaneum exposed to different concentrations of Platycladus orientalis leaves oil.

other insects. Intercept of time analysis lines showed that mortality of $C$. maculatus started faster than other tested insects (Tables 2 and 3).

Our study showed that insecticidal activity of $P$. orientalis varied with plant derived material, insect species, different concentrations of the oils and exposure time (Figures 1 and 2). Essential oil of leaves was more toxic than the fruit oil on the three species of insects. In the same way, Jeon et al. (2005) revealed that insecticidal activitiy of $P$. orientalis leaves oils against $4^{\text {th }}$-instar larvae of Aedes aegypti and Culex pipiens pallens was significantly higher than stem, fruit, and seed oils. The observed differences in the effects produced by the essential oils could be due to the presence of different secondary metabolites in both vegetal organs (Murray et al., 2005). The essential oil of the fruit of $P$. orientalis was tested against Acanthoscelides obtectus. The test revealed increased neonate larval mortality (Papachristos and Stamopoulos, 2002). The oils has also shown antimicrobial and fungitoxic properties (Hassanzadeh et al., 2001; Guleria et al., 2008) and antitumoral, cytotoxic, and antioxidant effects (Kosuge et al., 1985; Emami et al., 2005; Emami et al., 2011a; 2011b). 

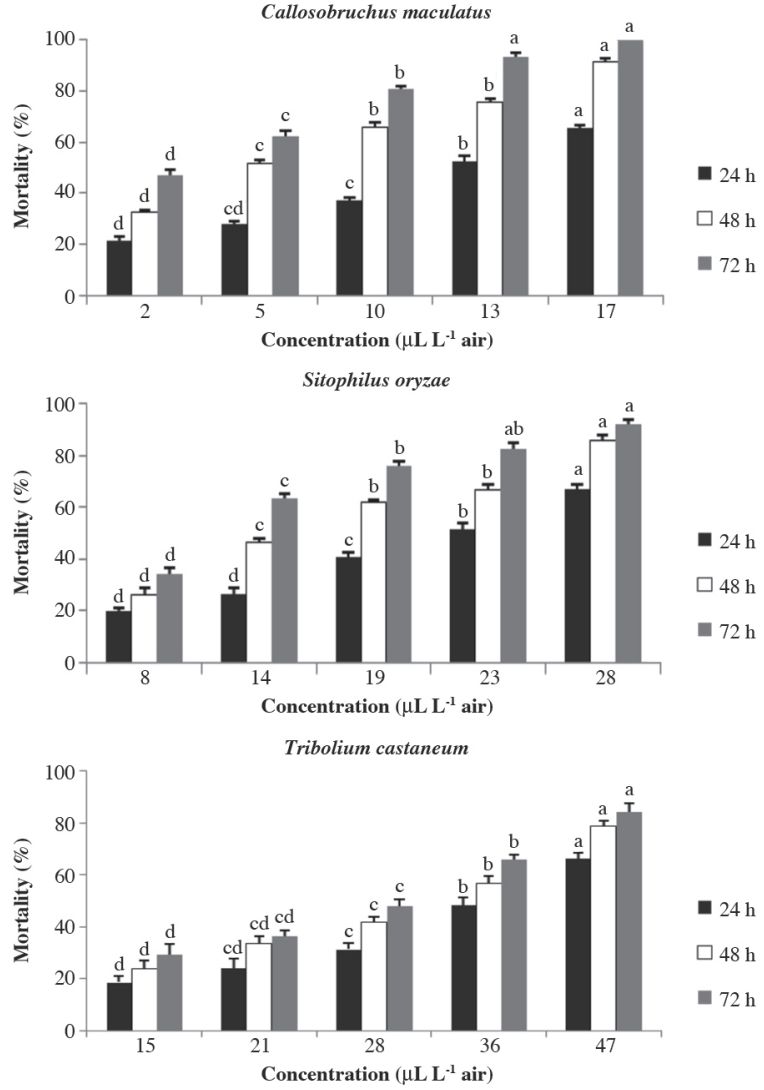

Different letters over columns indicate significant differences according to Tukey test at $\alpha$ $=0.01$. Columns with the same letter are not significantly different. Vertical bars indicate standard error $( \pm)$.

Figure 2. Mean mortality (\%) of Callosobruchus maculatus, Sitophilus oryzae, and Tribolium castaneum exposed to different concentrations of Platycladus orientalis fruit essential oil.

Extracts of $P$. orientalis have been shown to possess a range of biological activities, including insecticidal action against larvae of malaria and Japanese encephalitis vector (Sharma et al., 2005), control of Potato leaf roll virus (PLRV) in potato plants (Al-Ani et al., 2010), antioxidant effects (Nizam and Mushfiq, 2007), and antifungal activity (Alinezhad et al., 2011). The molluscicidal activity of extracts and leaf powder of $P$. orientalis was studied against the snail Lymnaea acuminata (Lamarck) (Singh and Singh, 2009).

In this research the essential oils of leaves and fruits from $P$. orientalis collected from region of Urmia, gave yellowish oils with a yield of $0.3 \%$ and $0.95 \%$, respectively, based on fresh weights. The yield of essential oils from leaf is relatively higher than other studies on $P$. orientalis in Iran (Nickavar et al., 2003; Emami et al., 2011a; 2011b). By contrast the yield of fruit oil is lower than other studies in Iran (Hassanzadeh et al., 2001; Nickavar et al., 2003; Emami et al., 2011a; 2011b).

GC-MS analyses of the oils were identified 26 compounds (92.9\%) and 23 constituents $(97.8 \%)$ in the leaf and the fruit oils, respectively (Table 1). The leaf and the fruit oils had compositions similar to those of other $P$. orientalis essential oils analyzed in Iran. Hassanzadeh $e t$ al. (2001) reported the main components of both the fruit and leaves oils were $\alpha$-pinene $(23.5 \%, 15 \%)$ sabinene $(11.1 \%, 10 \%)$ and $\alpha$-cedrol $(7.2 \%, 11.7 \%)$. Nickavar et al. (2003) also studied the composition of the leaf and fruits oils of $P$. orientalis. The leaf oil contained $\alpha$-pinene $(21.9 \%), \alpha$-cedrol $(20.3 \%)$, and $\Delta 3$-carene $(10.5 \%)$ as main components; while the fruit oil contained $\alpha$-pinene (52.4\%), $\Delta 3$-carene $(14.2 \%)$, and $\alpha$-cedrol (6.5\%). Emami et al. (2011a) reported the main components of the leaf oil were $\alpha$-pinene (15.5\%), $\Delta 3$-carene (10.8\%), and lingofolene $(9.8 \%)$. In the other hand $\alpha$-pinene (37.3\%), sabinene (8.0\%), and $\beta$-phellandrene (7.9\%) were the major components of the oil of the fruit of this plant. In the another study the major compounds in both oils with $\alpha$-pinene being the major constituent at levels of $14.5 \%$ and $39.3 \%$ for leaf and fruit oil, respectively (Emami et al., 2011b). Afsharypuor and Nayebzadeh (2009) analyzed oils of young stem, leaf and fruit of $P$. orientalis and reported the main constituents of the fruit oil were $\alpha$-pinene $(38.7 \%), \Delta 3$-carene $(20.4 \%)$, and $\alpha$-fenchene $(5.0 \%)$, while the major components of the leaf oil were $\alpha$-pinene $(30.0 \%), \Delta 3$-carene $(21.7 \%)$, and $\beta$-caryophyllene (6.9\%). On the other hands, the main constituents of the young stem oil were $\Delta 3$-carene

Table 2. Results of the leaf oil probit analysis to calculate $\mathrm{LC}_{50}, \mathrm{LC}_{\mathbf{9 5}}, \mathrm{LT}_{\mathbf{5 0}}$, and $\mathrm{LT}_{\mathbf{9 5}}$ values.

\begin{tabular}{|c|c|c|c|c|c|c|c|}
\hline Insect species & Time & $\mathrm{LC}_{50}$ & $\mathrm{LC}_{95}$ & $\chi^{2}[\mathrm{df}=3]$ & $p$ & Intercept & Slope \\
\hline \multirow[t]{3}{*}{ Callosobruchus maculatus } & 24 & 6.06 & 52.46 & $2.23^{\mathrm{a}}$ & 0.52 & 3.63 & 1.75 \\
\hline & 48 & 2.99 & 18.06 & 4.37 & 0.22 & 4.00 & 2.10 \\
\hline & 72 & 2.21 & 9.27 & 3.37 & 0.33 & 4.09 & 2.64 \\
\hline \multirow[t]{3}{*}{ Sitophilus oryzae } & 24 & 18.22 & 85.95 & 1.15 & 0.76 & 1.93 & 2.44 \\
\hline & 48 & 11.08 & 43.44 & 1.09 & 0.77 & 2.11 & 2.77 \\
\hline & 72 & 9.07 & 28.26 & 1.67 & 0.64 & 1.81 & 3.33 \\
\hline \multirow[t]{3}{*}{ Tribolium castaneum } & 24 & 32.07 & 129.91 & 0.40 & 0.94 & 0.93 & 2.70 \\
\hline & 48 & 26.31 & 114.69 & 1.27 & 0.73 & 1.35 & 2.57 \\
\hline & 72 & 22.54 & 74.68 & 2.23 & 0.52 & 0.73 & 3.16 \\
\hline Insect species & & $\mathrm{LT}_{50}[\mathrm{~h}]$ & $\mathrm{LT}_{95}[\mathrm{~h}]$ & $\chi^{2}[\mathrm{df}=1]$ & $p$ & Intercept & Slope \\
\hline C.maculatus & & $12.87^{\mathrm{b}}$ & 37.50 & $0.55^{\mathrm{a}}$ & 0.45 & 1.07 & 3.54 \\
\hline S. oryzae & & 15.25 & 48.40 & 0.56 & 0.45 & 1.12 & 3.27 \\
\hline T. castaneum & & 11.31 & 123.28 & 0.21 & 0.64 & 3.33 & 1.58 \\
\hline
\end{tabular}

Since goodness-of-fit Chi square is not significant $(\mathrm{P}>0.15)$, no heterogeneity factor is used.

${ }^{b}$ Lethal time values were calculated at the highest concentrations (13 $\mu \mathrm{L} \mathrm{L}^{-1}$ for Callosobruchus maculatus, $28 \mu \mathrm{L} \mathrm{L}^{-1}$ for Sitophilus oryzae and $47 \mu \mathrm{L} \mathrm{L}^{-1}$ for Tribolium castaneum). 
Table 3. Results of the fruit oil probit analysis to calculate $\mathrm{LC}_{50}, \mathrm{LC}_{95}, \mathrm{LT}_{50}$, and $\mathrm{LT}_{95}$ values.

\begin{tabular}{|c|c|c|c|c|c|c|c|}
\hline Insect species & Time & $\mathrm{LC}_{50}$ & $\mathrm{LC}_{95}$ & $\chi^{2}[\mathrm{df}=3]$ & $p$ & Intercept & Slope \\
\hline \multirow[t]{3}{*}{ Callosobruchus maculatus } & 24 & 9.24 & 122.33 & $1.44^{\mathrm{a}}$ & 0.69 & 3.59 & 1.46 \\
\hline & 48 & 3.98 & 27.19 & 1.43 & 0.69 & 3.82 & 1.97 \\
\hline & 72 & 2.60 & 13.19 & 3.43 & 0.32 & 4.03 & 2.33 \\
\hline \multirow[t]{3}{*}{ Sitophilus oryzae } & 24 & 21.56 & 107.62 & 1.18 & 0.75 & 1.86 & 2.35 \\
\hline & 48 & 14.27 & 54.15 & 0.90 & 0.82 & 1.72 & 2.84 \\
\hline & 72 & 10.90 & 36.73 & 0.16 & 0.98 & 1.77 & 3.11 \\
\hline \multirow[t]{3}{*}{ Tribolium castaneum } & 24 & 36.58 & 148.65 & 0.81 & 0.84 & 0.78 & 2.70 \\
\hline & 48 & 29.23 & 107.57 & 0.96 & 0.81 & 0.74 & 2.90 \\
\hline & 72 & 25.63 & 89.16 & 1.09 & 0.77 & 0.99 & 3.03 \\
\hline Insect species & & $\mathrm{LT}_{50}[\mathrm{~h}]$ & $\mathrm{LT}_{95}[\mathrm{~h}]$ & $\chi^{2}[\mathrm{df}=1]$ & $p$ & Intercept & Slope \\
\hline C. maculatus & & $18.89^{\mathrm{b}}$ & 50.94 & $0.51^{\mathrm{a}}$ & 0.47 & 0.13 & 3.81 \\
\hline S. oryzae & & 14.55 & 92.52 & 0.00 & 0.94 & 2.62 & 2.04 \\
\hline T. castaneum & & 10.72 & 245.91 & 0.00 & 0.97 & 3.76 & 1.20 \\
\hline
\end{tabular}

asince goodness-of-fit Chi square is not significant $(\mathrm{P}>0.15)$, no heterogeneity factor is used.

${ }^{b}$ Lethal time values were calculated at the highest concentrations ( $13 \mu \mathrm{L} \mathrm{L}^{-1}$ for Callosobruchus maculatus, $28 \mu \mathrm{L} \mathrm{L}^{-1}$ for Sitophilus oryzae and $47 \mu \mathrm{L} \mathrm{L}{ }^{-1}$ for Tribolium castaneum)

(24.3\%), $\alpha$-pinene (15.4\%), and cedrol (17.7\%).

In comparison with published data, it could be clearly shown that ingredients of the essential oil of fruit and leaves of $P$. orientalis are similar, but with differences in their percentage depending distinctly on the region in which they are grown. Most notable differences observed in the composition of $P$. orientalis grown in Urmia (Nazlo) included the absence of cis-thujopsene, camphene, a-copaene, $O$-cymene, cis-p-menth-2-en-1$\mathrm{ol}$, and viridiflorene, and the high percentage of a-pinene 35.2 and $50.7 \%$ for leaves and the fruit, respectively (Hassanzadeh et al., 2001; Nickavar et al., 2003; Afsharypuor and Nayebzadeh, 2009; Emami et al., 2011a; 2011b).

$\alpha$-Pinene, a monoterpenoid, is the major component in $P$. orientalis essential oil. There are numerous reports on biological activity of $\alpha$-pinene. Ojimelukwe and Adler (1999) found $\alpha$-pinene was toxic to Tribolium confusum $\mathrm{du}$ Val. The antifeedant and growth inhibitory effects of this monoterpene toward $T$. castaneum were observed by Huang et al. (1998). $\alpha$-Pinene possesses important repellent effects toward T. confusum (Tapondjou et al., 2005), and has shown strong fumigant toxicity against Acanthoscelides obtectus (Regnault-Roger and Hamraoui, 1995).

Limonene, $\beta$-caryophyllene, myrcene, $\rho$-cymene, terpinolene, and bornyl acetate are the other components of $P$. orientalis oil that have insecticidal activity. For example, limonene had insecticidal and repellent bioactivities to T.castaneum (Lee et al., 2002; Garcia et al., 2005). $\beta$-Caryophyllene from Eupatorium betonicaeforme (D.C.) Baker (Asteraceae) has been reported as larvicidal toward Aedes egyptii (L.) (Albuquerque et al., 2004). Toxic effect of myrcene have been evaluated on S. oryzae (Coats et al., 1991), $\rho$-cymene had fumigant toxicity on Acanthoscelides obtectus (Regnault-Roger and Hamraoui, 1995) and terpinolene and bornyl acetate showed contact and fumigant toxicity against $S$. oryzae (Park et al., 2003).

So the toxic effects of $P$. orientalis oil could be attributed to $\alpha$-pinene and other components. As major constituents of $P$. orientalis are monoterpenoids, they are typically volatile and rather lipophilic compounds that can penetrate into insects rapidly and interfere with their physiological functions (Lee et al., 2002). Due to their high volatility they have fumigant activity that might be of importance for controlling stored-product insects (Ahn et al., 1998).

Experiments showed that $T$. castaneum is more tolerant than S. oryzae and C. maculatus (Tables 2 and 3). Negahban and Moharramipour (2007) reported fumigant toxicity of essential oils from Eucalyptus intertexta R.T. Baker, Eucalyptus sargentii Maiden and Eucalyptus camaldulensis Dehnh (Myrtaceae) against T. castaneum, $S$. oryzae, and $C$. maculatus. The $\mathrm{LC}_{50}$ values to the selected essential oils were between 2.55 and $3.97 \mu \mathrm{L}$ $\mathrm{L}^{-1}$ air for C. maculatus, 6.93 and $12.91 \mu \mathrm{L} \mathrm{L}^{-1}$ air for $S$. oryzae, and 11.59 and $33.50 \mu \mathrm{L} \mathrm{L}^{-1}$ air for T. castaneum. Sahaf et al. (2007) studied fumigant toxicity of Carum copticum C.B. Clarke (Apiaceae) essential oil against $S$. oryzae and $T$. castaneum. They reported that $T$. castaneum $\left(\mathrm{LC}_{50}=33.14 \mu \mathrm{L} \mathrm{L}^{-1}\right.$ air $)$ was significantly more tolerant than $S$. oryzae $\left(\mathrm{LC}_{50}=0.91 \mu \mathrm{L} \mathrm{L}^{-1}\right.$ air). Ogendo et al. (2008) demonstrated that $T$. castaneum was more tolerant than other tested species. $\mathrm{LC}_{50}$ values for $S$. oryzae, Rhyzopertha dominica (F.), Oryzaephilus surinamensis (L.), and Callosobruchus chinensis (L.) adults ranged from 0.20 to $14 \mu \mathrm{L} \mathrm{L}^{-1}$ air, 0.01 to $17 \mu \mathrm{L} \mathrm{L}^{-1}$ air, and 0.80 to $23 \mu \mathrm{L} \mathrm{L}^{-1}$ air $24 \mathrm{~h}$ after treatment with Ocimum gratissimum L. (Lamiaceae) essential oil, eugenol, and b-(Z)-ocimene, respectively. Fumigant toxicity of Artemisia sieberi Besser (Asteracae) essential oil against T. castaneum, S. oryzae, and C. maculatus was evaluated by Negahban et al. (2007). Callosobruchus maculatus was significantly more susceptible than $S$. oryzae and T. castaneum; the $\mathrm{LC}_{50}$ values were $1.45 \mu \mathrm{L} \mathrm{L}^{-1}$ air for C. maculatus, $3.86 \mu \mathrm{L} \mathrm{L}^{-1}$ air for $S$. oryzae, and 16.76 $\mu \mathrm{L} \mathrm{L}^{-1}$ air for T. castaneum. Fumigant toxicity of Vitex pseudonegundo (Hausskn.) Hand.-Mazz. (Lamiaceae) essential oil against $T$. castaneum and $S$. oryzae was evaluated by Sahaf et al. (2008), demonstrating that $S$. oryzae $\left(\mathrm{LC}_{50}=31.96 \mu \mathrm{L} \mathrm{L}^{-1}\right.$ air) was more susceptible than $T$. castaneum $\left(\mathrm{LC}_{50}=47.27 \mu \mathrm{L} \mathrm{L}^{-1}\right.$ air). These 
findings are consistent with the results of this study as C. maculatus was more susceptible to the essential oils, and $T$. castaneum was more tolerant than $S$. oryzae and $C$. maculatus.

\section{CONCLUSIONS}

This study demonstrated that the essential oil from the leaf of $P$. orientalis was more toxic than the fruit oil on C. maculatus, S. oryzae, and T. castaneum. Both oils in the same concentration were tested on each species and $T$. castaneum was more tolerant than other species. GC-MS analysis of the oils revealed that the percentage of monoterpene hydrocarbons was higher than other components. The major hydrocarbon was $\alpha$-pinene both in the leaf and the fruit. Therefore, oils of $P$. orientalis possess a potential for use in the management of S. oryzae, T. castaneum, and especially C. maculatus. Further studies need to be conducted on these essential oils against other insects (e.g. Rhyzopertha dominica).

\section{ACKNOWLEDGEMENTS}

Authors would like to thank A. Abdolmaleki and A. Ebadollahi for excellent technical support during experiments.

\section{Componentes químicos y toxicidad de aceites esenciales de tuya oriental, Platycladus orientalis (L.) Franco, contra tres escarabajos de productos almacenados.} Los metabolitos secundarios de las plantas juegan un papel importante en las interacciones planta-insecto, y por lo tanto pueden tener actividad insecticida o biológica en los insectos. La toxicidad fumigante de los aceites esenciales de hojas y frutos del árbol oriental de la vida (Platycladus orientalis (L.) Franco) (Cupressaceae) fue investigada contra adultos de gorgojo del guisante (Callosobruchus maculatus Fab.), gorgojo del arroz (Sitophilus oryzae L.), y escarabajo rojo de la harina (Tribolium castaneum Herbst). Las hojas frescas y las frutas fueron sometidas a hidrodestilación utilizando un aparato tipo Clevenger y la composición química de los aceites volátiles se estudió por cromatografía de gas-espectrometría de masa (GC-MS). Se identificaron $26(92,9 \%)$ y 23 compuestos $(97,8 \%)$ en los aceites de hoja y de frutos, respectivamente. Los componentes principales de los aceites de hojas y frutos fueron $\alpha$-pineno $(35,2 \%, 50,7 \%), \alpha$-cedrol $(14,6 \%, 6,9 \%)$ y $\Delta$-3-careno $(6,3 \%, 13,8 \%)$, respectivamente. Ambos aceites fueron probados en la misma concentración por su toxicidad fumigante en cada especie. Los aceites de hoja fueron más tóxicos que los de fruto contra tres especies de insectos. Callosobruchus maculatus fue más susceptible que $S$. oryzae, y $T$. castaneum. Los valores de $\mathrm{CL}_{50}$ de aceites de hojas y frutos a las 24 h se estimó 6,06 y 9,24 $\mu \mathrm{L} \mathrm{L}^{-1} \mathrm{de}$ aire de $C$. maculatus, 18,22 y $21,56 \mu \mathrm{L} \mathrm{L}^{-1} \mathrm{de}$ aire para $S$. oryzae, y 32,07 y $36,58 \mu \mathrm{L} \mathrm{L}^{-1}$ de aire para
T. castaneum, respectivamente. Estos resultados sugieren que aceites de $P$. orientalis pueden tener potencial como agente de control de C. maculatus, $S$. oryzae, y $T$. castaneum.

Palabras clave: insecticidas botánicos, fumigación, Platycladus orientalis, insectos de productos almacenados.

\section{LITERATURE CITED}

Abbott, W.S. 1925. A method for computing the effectiveness of an insecticide. Journal of Economic Entomology 18:265-267.

Adams, R.P. 1995. Identification of essential oil components by gas chromatography/mass spectroscopy. Allured Publishing, Carol Stream, Illinois, USA.

Afsharypuor, S., and B. Nayebzadeh. 2009. Essential oil constituents of young stem, leaf and fruit of Platycladus orientalis (L.) Franco grown in Isfahan (Iran). Journal of Essential Oil Research 21:525528.

Ahn, Y.J., S.B. Lee, H.S. Lee, and G.H. Kim. 1998. Insecticidal and acaricidal activity of carvacrol and b-thujaplicine derived from Thujopsis dolabrata var. hondai sawdust. Journal of Chemical Ecology 24:1-90.

Al-Ani, R.A., S.N.H. Diwan, and M.A. Adhab. 2010. Efficiency of Thuja orientalis and Artimisia campestris extracts to control of Potato leaf roll virus (PLRV) in potato plants. Agriculture and Biology Journal of North America 1:579-583.

Albuquerque, M.R., E.R. Silveira, D.E. Uchoa, T.L. Lemos, E.B. Souza, G.M.P. Santiago, and O.D.L. Pessoa. 2004. Chemical composition and larvicidal activity of the essential oils from Eupatorium betonicaeforme (D.C.) Baker (Asteraceae). Agricultural and Food Chemistry 52: 6708-6711.

Alinezhad, S., A. Kamalzadeh, M. Shams-Ghahfarokhi, M.B. Rezaee, K. Jaimand, M. Kawachi, et al. 2011. Search for novel antifungals from 49 indigenous medicinal plants: Foeniculum vulgare and Platycladus orientalis as strong inhibitors of aflatoxin production by Aspergillus parasiticus. Annals of Microbiology 61:673-681. doi:10.1007/s13213-010-0194-1.

Assadi, M. 1998. Cupressaceae. p. 11-12. In Assadi, M., M. Khatamsaz, A.A. Maassomi, and V. Mozafarian (eds.) Flora of Iran. Vol. 21. Research Institute of Forest and Rangelands, Tehran, Iran.

Benzi, V., N. Stefanazzi, and A.A. Ferrero. 2009. Biological activity of essential oils from leaves and fruits of pepper tree (Schinus molle L.) to control rice weevil (Sitophilus oryzae L.). Chilean Journal of Agricultural Research 69:154-159.

Coats, J.R., L.L. Karr, and C.D. Drewes. 1991. Toxicity and neurotoxic effects of monoterpenoids in insects and earthworms. p. 305-316. In Hedin, P.A. (ed.) Naturally occurring pest bioregulators. ACS Symposium Series $\mathrm{N}^{\circ}$ 449. American Chemical Society, Washington DC., USA.

Comerford, S.C. 1996. Medicinal plants of two Mayan healers from San Andres, Peten, Guatemala. Economic Botany 50:327-336.

Emami, S.A., S. Asgary, M.R.S. Ardekani, G.A. Naderi, T. Kasher, S. Aslani, et al. 2011b. Antioxidant activity in some in vitro oxidative systems of the essential oils from the fruit and the leaves of Platycladus orientalis. Journal of Essential Oil Research 23:8390.

Emami, S.A., J. Asili, M. Malekian, and M.K. Hassanzadeh. 2011a. Antioxidant effects of the essential oils of different parts of Platycladus orientalis L. (Franco) and their components. Journal of Essential Oil Bearing Plants 14:334-344.

Emami, S.A., H. Sadeghi-Aliabadi, M. Saeidi, and A. Jafarian. 2005. Cytotoxic evaluations of Iranian conifers on cancer cells. Pharmaceutical Biology 43:299-304.

Garcia, M., O.J. Donadel, C.E. Ardanaz, C.E. Tonn, and M.E. Sosa. 2005. Toxic and repellent effects of Baccharis salicifolia essential oil on Tribolium castaneum. Pest Management Science 61:612618. 
Guleria, S., A. Kumar, and A.K. Tiku. 2008. Chemical composition and fungitoxic activity of essential oil of Thuja orientalis L. grown in the north-western Himalaya. Zeitschrift für Naturforschung. Section C. Journal of Biosciences 63:211-214.

Haque, M.A., H. Nakakita, H. Ikenaga, and N. Sota. 2000. Development-inhibiting activity of some tropical plants against Sitophilus zeamais Motschulsky (Coleoptera: Curculionidae). Journal of Stored Products Research 36:281-287.

Hassanzadeh, M.K., M. Rahimizadeh, B.S. Fazly Bazzaz, S.A. Emami, and J. Assili. 2001. Chemical and antimicrobial studies of Platycladus orientalis essential oils. Pharmaceutical Biology 39:388-390.

Huang, Y., S.K. Lee, and S.H. Ho. 1998. Antifeedant and growth inhibitory effects of $\alpha$ - pinene on stored-product insects, Tribolium castaneum (Herbst) and Sitophilus zeamais (Mostch). International Pest Control 40:18-20.

Isman, M.B. 2000. Plant essential oils for pest and disease management. Crop Protection 19:603-608.

Isman, M.B. 2006. Botanical insecticides, deterrents, and repellents in modern agriculture and an increasingly regulated world. Annual Review of Entomology 51:45-66.

Jeon, J.H., S.H. Lee, M.K. Kim, and H.S. Lee. 2005. Larvicidal activity of Chamaecyparis obtusa and Thuja orientalis leaf oils against two mosquito species. Agricultural Chemistry and Biotechnology 48:26-28.

Keita, M.S., C.h. Vincent, J.P. Schmidt, and J.T. Arnasson. 2001. Insecticidal effects of Thuja occidentalis (Cupressaceae) essential oil on Callosobruchus maculates (Coleoptera: Bruchidae). Canadian Journal of Plant Science 81:173-177.

Kosuge, T., M. Yokota, K. Sugiyama, and T. Yamamoto. 1985. Studies on antitumor activities and antitumor principles of Chinese herbs. I. Antitumor activities of Chinese herbs. Yakugaku Zasshi 105:791-795.

Kosuge, T., M. Yokota, M. Yoshida, and A. Ochiai. 1981. Studies on antihemorrhagic principles in the crude drugs for hemostatics. I. On hemostatic activities of the crude drugs for hemostatics. Yakugaku Zasshi 101:501-503.

Lee, B.H., S.E. Lee, P.C. Annis, S.J. Pratt, B.S. Park, and F. Tumaalii. 2002. Fumigant toxicity of essential oils and monoterpenes against the red flour beetle, Tribolium castaneum Herbst. Journal of Asia-Pacific Entomology 5:237-240.

Mikage, M., H. Yagawa, M. Yoshizaki, K. Kimura, and T. Namba. 1984. Pharmacognostical studies on "Cebaiye" (1) On the botanical origin of the crude drug derived from Thuja orientalis L. and its similar plants. Shoyakugaku Zasshi 38:327-333.

Murray, A.P., M.A. Frontera, M.A. Tomas, and M.C. Mullet. 2005. Gas chromatography-mass spectrometry study of the essential oil of Schinus longifolia (Lindl.) Speg., Schinus fasciculate (Griseb.) I.M. Johnst., and Schinus areira (L.). Zeitschrift für Naturforschung. Section C. Journal of Biosciences 60:25-29.

Negahban, M., and S. Moharramipour. 2007. Fumigant toxicity of Eucalyptus intertexta, Eucalyptus sargentii and Eucalyptus camaldulensis against stored-product beetles. Journal of Applied Entomology 131:256-261.

Negahban, M., S. Moharramipour, and F. Sefidkon. 2007. Fumigant toxicity of essential oil from Artemisia sieberi Besser against three stored-product insects. Journal of Stored Products Research 43:123-128.

Nickavar, B., G. Amin, and S. Parhami. 2003. Volatile constituents of the fruit and leaf oils of Thuja orientalis L. grown in Iran. Zeitschrift für Naturforschung Teil C Biochemie Biophysik Biologie Virologie 58:171-172.
Nizam, I., and M. Mushfiq. 2007. Antioxidant activity of water and alcohol extracts of Thuja orientalis leaves. Oriental Pharmacy and Experimental Medicine 7:65-73.

Ogendo, J.O., M. Kostyukovsky, U. Ravid, J.C. Matasyoh, A.L. Deng, E.O. Omolo, et al. 2008. Bioactivity of Ocimum gratissimum L. oil and two of its constituents against five insect pests attacking stored food products. Journal of Stored Products Research 44:328-334.

Ojimelukwe, P.C., and C. Adler. 1999. Potential of zimtaldehyde, 4-allylanisol, linalool, terpineol and other phytochemicals for the control of confused flour beetle (Tribolium confusum J.D.V.) (Col: Tenebrionidae). Journal of Pesticide Science 72:81-86.

Panthong, A., D. Kanjanapothi, and W.C. Taylor. 1986 Ethnobotanical review of medicinal plants from Thai traditional books. Part I: Plants with anti-inflammatory, antiasthmatic and antihypertensive properties. Journal of Ethnopharmacology 18:213-228

Papachristos, D.P., and D.C. Stamopoulos. 2002. Repellent, toxic and reproduction inhibitory effects of essential oil vapours on Acanthoscelides obtectus (Say) (Coleoptera: Bruchidae). Journal of Stored Products Research 38:117-128.

Park, C., S.G. Lee, D.H. Choi, J.D. Park, and Y.J. Ahn. 2003 Insecticidal activities of constituents identified in the essential oil from leaves of Chamaecyparis obtusa against Callosobruchus chinensis (L.) and Sitophilus oryzae (L.). Journal of Stored Products Research 39:375-384.

Pavela, R. 2005. Insecticidal activity of some essential oils against larvae of Spodoptera littoralis. Fitoterapia 76:691-696.

Regnault-Roger, C., and A. Hamraoui. 1995. Fumigant toxic activity and reproductive inhibition induced by monoterpenes on Acanthoscelides obtectus (Say) (Coleoptera), a bruchid of kidney bean (Phaseolus vulgaris L.). Journal of Stored Products Research 31:291-299.

Sahaf, B.Z., S. Moharramipour, and M.H. Meshkatalsadat. 2007. Chemical constituents and fumigant toxicity of essential oil from Carum copticum against two stored product beetles. Insect Science 14:213-218.

Sahaf, B.Z., S. Moharramipour, and M.H. Meshkatalsadat. 2008 Fumigant toxicity of essential oil from Vitex pseudo-negundo against Tribolium castaneum (Herbst) and Sitophilus oryzae (L). Journal of Asia-Pacific Entomology 11:175-179.

Sharma, P., L. Mohan, and C.N. Srivastava. 2005. Larvicidal potential of Nerium indicum and Thuja orientalis extracts against malaria and Japanese encephalitis vector. Journal of Environmental Biology 26:657-660.

Sharma, S., V. Nagar, B.K. Mehta, and P. Singh. 1993. Diterpenoides from Thuja orientalis leaves. Fitoterapia 64:476-477.

Singh, A., and V.K. Singh. 2009. Molluscicidal activity of Saraca asoca and Thuja orientalis against the fresh water snail Lymnaea acuminata. Veterinary Parasitology 164:206-210.

Tapondjou, A.L., C. Adler, D.A. Fontem, H. Bouda, and C. Reichmut 2005. Bioactivities of cymol and essential oils of Cupressus sempervirens and Eucalyptus saligna against Sitophilus zeamais (Motschulsky) and Tribolium confusum (du Val). Journal Stored Product Research 41:91-102.

Zhu, J.X., Y. Wang, L.D. Kong, C. Yang, and X. Zhang. 2004. Effects of Biota orientalis extract and its flavonoid constituents, quercetin and rutin on serum uric acid levels in oxonate-induced mice and xanthine dehydrogenase and xanthine oxidase activities in mouse liver. Journal of Ethnopharmacology 93:133-140. 